\title{
Problem Solving Ability of Integration Technique in Integral Calculus Learning Based on APOS Model of Mathematics Education Students
}

\author{
Hanifah* \\ Department of Mathematics Education, University of Bengkulu \\ "Corresponding author.Email: hanifah@unib.ac.id
}

\begin{abstract}
This study aimed to determine the results of the posttest, and the students' problem-solving abilities in solving integration technical questions in learning Integral Calculus based on the APOS Model. The integration technique consists of: a) Substitution Method, b) Trigonometric Substitution, c) Substitution that rationalizes, d) Partial Integral, e) Integral rational function. The APOS model is student-centered learning and has a syntax that consists of phases: Orientation, Practicum, Small Group Discussion, Class Discussion, Exercise, and Evaluation. The research subjects were 28 students of the $3^{\text {rd }}$ semester of Mathematics Education FKIP Unib 2019/2020 who took Integral calculus class. The instruments used were posttest sheets and questionnaires. The method or flow used was: carrying out the posttest; checking answers based on the Polyas stages, which consisted of: 1) Understanding the Problem; 2) Plan; 3) Doing the Plan; and 4) Looking Back. Post-test questions for the integration technique consisted of 7 questions. Problem 1 was about Substitution Method, Problem 2 and problem 3 were about Trigonometric Functions, Problem 4 was about Substitution that rationalizes, Problem 5 was about Partial Integral, Problem 6 and 7 were about Rational Function Integration Technique. From the research results, it can be concluded that: the average value of the post-test results was 63.04. The average ability of students to solve problems regarding integration techniques: a) substitution methods, there were: 1) $96.43 \%$ was able to understand the problem: 2) $96.43 \%$ were able to make plans: 3) $96.43 \%$ were able to do the plan; 4) only $64.29 \%$ were able to do the looking back. b) Trig substitution, there were: 1) $51.79 \%$ were able to understand the problem: 2) $51.79 \%$ were able to make plans: 3) $51.79 \%$ were able to do the plan: 4) $51.79 \%$ were able to do the looking back. c) Substitution that rationalizes, there were: 1) $58.93 \%$ were able to understand the problem: 2) $37.5 \%$ were able to make plans: 3) $39.29 \%$ were able to do the plan; 4) only $14.29 \%$ were able to do the looking back., d) Partial Integral, there were: 1) $60.71 \%$ were able to understand the problem: 2) $53.57 \%$ were able to make plans: 3 ) $14.29 \%$ were able to do the plan; 4) only $14.29 \%$ were able to do the looking back., e) Integral rational functions, there were: 1) $85.715 \%$ were able to understand problems: 2) $75 \%$ were able to make plans: 3) $46.43 \%$ were able to do plan; 4) only $41,075 \%$ were able to do the looking back. Based on the answers to the open questionnaire, the difficulty faced by students in general was the confusion in determining the formulas to be used especially for the integration technique of trigonometric functions.
\end{abstract}

Keywords: APOS model, Integral calculus, Integration technique, Polya problem solving.

\section{INTRODUCTION}

Integral Calculus is a compulsory subject offered in the Mathematics Education Study Program FKIP Unib with 4 (3-1) credits. Integration Technique is a material that must be studied in Integral Calculus subject. Integration Technique consists of these following subjects: Integration with Substitution, Multiple
Trigonometric Integral, Rational Substitution, Partial Integral, and Rational Function Integration [1]. Each subject has a high level of difficulty and requires complete mastery of the prerequisite material.

Integral Calculus learning in the Class $\mathrm{B}$ at Mathematics Education Study Program FKIP Unib academic year of 2019/2020 took place by applying a Learning Model based on Theory of Action, Process, 
Objects, and Schemes (APOS Model). The APOS model is a student-centered learning model and has a syntax consisting of phases: Orientation, Practicum, Small Group Discussions, Class Discussions, Exercises, and Evaluation [2][3]. The application of the APOS Model to Integral Calculus learning in the Mathematics Education Study Program since the academic year of 2017/2018, 2018/2019 had had a major influence on students who carried it out. Students were becoming more: resilient, critical, confident, and caring [4][5][6].

The application of the APOS Model was supported by the APOS Model-based Worksheet. Students work in small and heterogeneous groups of 3-4 people. In the Orientation phase, the worksheet contained information about the material to be studied. In the Practicum phase, the student worksheet contained the Maple application program instructions on integration techniques that were executed by students using laptops. The results of this Maple execution were expected to help students understand the material of integration techniques. To help students understand the results of Maple's execution, in the Small Group Discussion phase, the Worksheet contained questions related to Maple's execution results and questions about integration techniques that were answered manually in small groups. To ensure that students understand the material on integration techniques, in the Class Discussion phase, each group of students presented the results of their group work. To strengthen students' understanding, the Worksheet Training phase contained questions with a higher difficulty level. Exercise questions can be used as homework assignments. In the evaluation phase, the lecturer can give a quiz or questionnaire about the implementation of Integral Calculus learning. After studying all integration techniques, a post-test on integration techniques was carried out to determine the learning outcomes and student abilities in solving integration technical problems.

The problem-solving ability of the Integration Technique posttest used in this study referred to Polya's procedures [7]. In general, according to Polya, there were 4 steps to solve a problem which were used as a basis for solving a problem, namely (1) Understanding the Problem. In this aspect, students need to identify what was known, what was available, the number, relationships and values associated with it, and what they were looking for. (2) Plan. In this aspect, students need to identify the operations involved to solve a given problem. (3) Carry out the Plan. In this aspect, the things that were applied depend on what had been planned previously, interpreted the information provided in mathematical form, and carried out the plan during the process and calculations that took place. (4) Re-checking. At this stage, things that need to be considered were checked back the important information, checked all the calculations that had been involved, considered whether the solution was logical, looked at other alternatives, and read the question again and asked yourself whether the question had really been answered [7][8].

\section{RESEARCH METHOD}

The research subjects were the students of third Semester Class B Mathematics Education FKIP Unib Year Academic 2019/2020 who took the Integral Calculus course, 28 people in total. The research location was at Room 16 of GB3 FKIP Unib. The instrument used was a posttest sheet. Each correct problem got 100 score and to analyze Polya's stages, for those who did nothing have a value of zero and value of one for those who solved the problem according to the indicator. The methods or flows that were used: carried out the posttest; checked answers based on Polya's stages which consisted of: 1) Understanding the Problem; 2) Making Plan; 3) Doing a Plan; and 4) Looking Back. Calculated the percentage of answers, and made conclusions.

\section{RESULTS AND DISCUSSION}

\subsection{Results of Students' Integration Techniques Posttest}

To find out the learning outcomes and problemsolving abilities of Polya's stages of the integration techniques, students were given the problem that was taken from Purcell as shown in Table 1 below [1][9].

Table 1. The Problem of Integration Techniques Posttest

\begin{tabular}{c|l|l}
\hline No & \multicolumn{1}{|c|}{ Problem } & \multicolumn{1}{|c}{$\begin{array}{c}\text { Name of Integration } \\
\text { Technique }\end{array}$} \\
\hline 1 & $\int \frac{2 \mathrm{x}}{\left(x^{2}-15\right)^{10} \mathrm{dx}}$ & $\begin{array}{l}\text { Integration with } \\
\text { Substitution }\end{array}$ \\
\hline 2 & $\int \sin ^{3} \mathrm{t} \cos (t) d t$ & Trigonometric Integral \\
\hline 3 & $\int \cos (8 t) \sin (4 t) d t$ & Trigonometric Integral \\
\hline 4 & $\int \cos ^{3}(10 \mathrm{t}) d t$ & Trigonometric Integral \\
\hline 5 & $\int \mathrm{x}^{4} \mathrm{e}^{\mathrm{x}^{2} d x}$ & Repeating Partial Integral \\
\hline 6 & $\int \frac{d x}{\sqrt{4-x^{2}}}$ & $\begin{array}{l}\text { Substitution that } \\
\text { Rationalizes }\end{array}$ \\
\hline
\end{tabular}




\begin{tabular}{c|c|l}
\hline No & \multicolumn{1}{|c|}{ Problem } & \multicolumn{1}{|c}{$\begin{array}{c}\text { Name of Integration } \\
\text { Technique }\end{array}$} \\
\hline 7 & $\int \frac{7 \mathrm{x}^{2}+3 \mathrm{x}-4}{(x-1)(x-2)(x+3)} \mathrm{dx}$ & $\begin{array}{l}\text { Integration of Rational } \\
\text { Functions }\end{array}$ \\
\hline
\end{tabular}

After the student's answers were checked and given a score based on the assessment criteria which was each of the problem got a 100 score and after that found the average score, the integration techniques outcomes were obtained as Figure 1. Based on Figure 1, it can be seen that the highest average was 100 and the lowest average was 15.7. The class average score $=61.1$. There were $53.57 \%$ who scored more than the class average. There were $39.29 \%$ who scored $>70$. The following Figure 2 was about the student average score for each of the Integration Techniques problem.

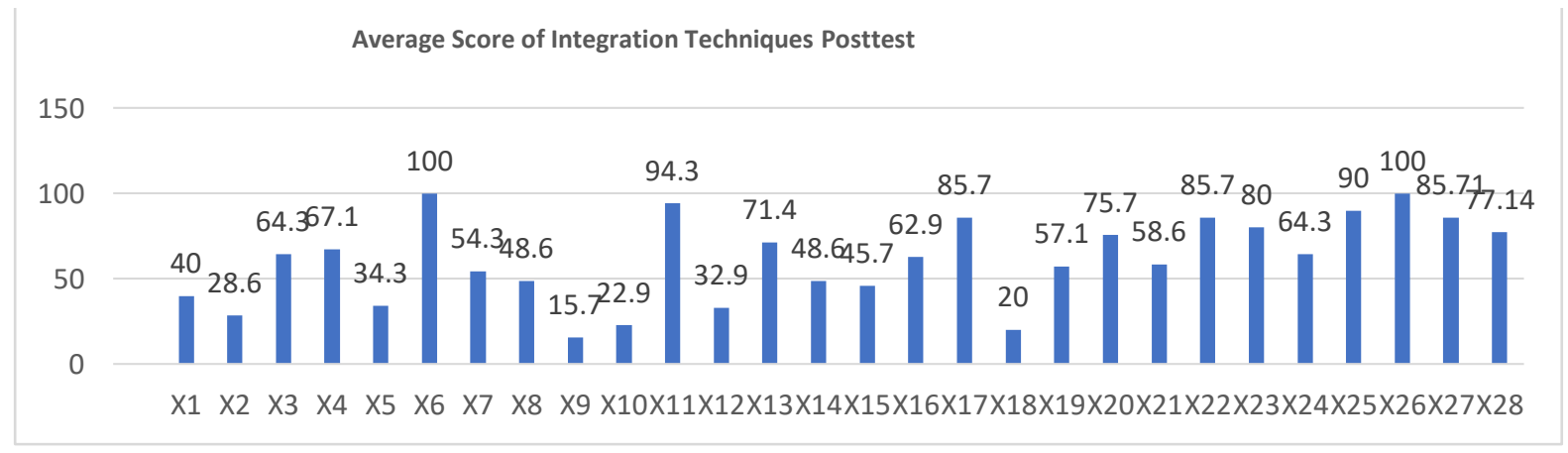

Figure 1. Average Score of Integration Techniques Posttest from Each Student

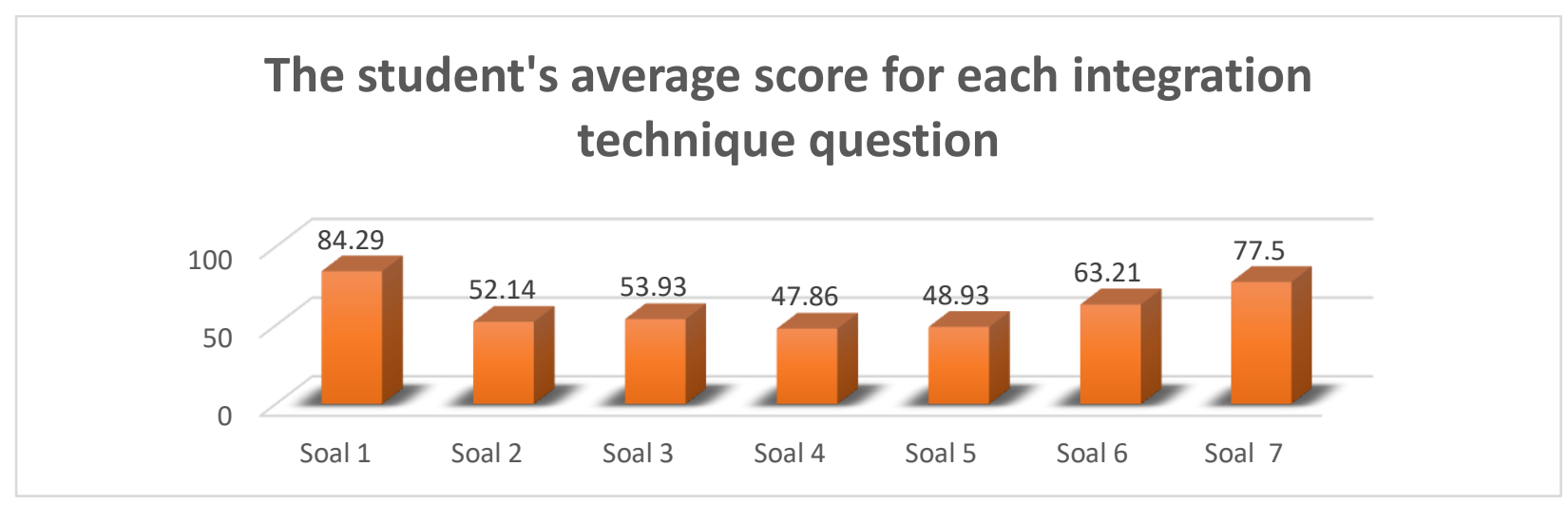

Figure 2. The Average Score of Integration Techniques Problem from Each Student

From Figure 2 it can be seen that the student average score for the integration technique of the substitution method got the highest score, was $84.29 \%$. This was possible because the substitution method had been implemented since the first Integral Calculus learning. It's just that the level of difficulty increased as more integration techniques were learned. Problem number 4 was about trigonometric integrals and repetitive partial integrals were the most difficult problem for students to solve. To solve these problems, it required students' understanding and skills.

\subsection{Average Value of Problem Solving Ability for Each Integration Technique Problem}

To find out the student's ability in solving the Integrated techniques Post-test problems, an analysis of the students' answers was carried out using the Polya stages consisted of: P1) Understanding the Problem; P2) Making a plan; P3) Carrying out a plan; and P4) Looking back. The results were shown in Table 2 below. 
Table 2. Problem Solving Ability Based on Polya Stages of Post-Test Problem

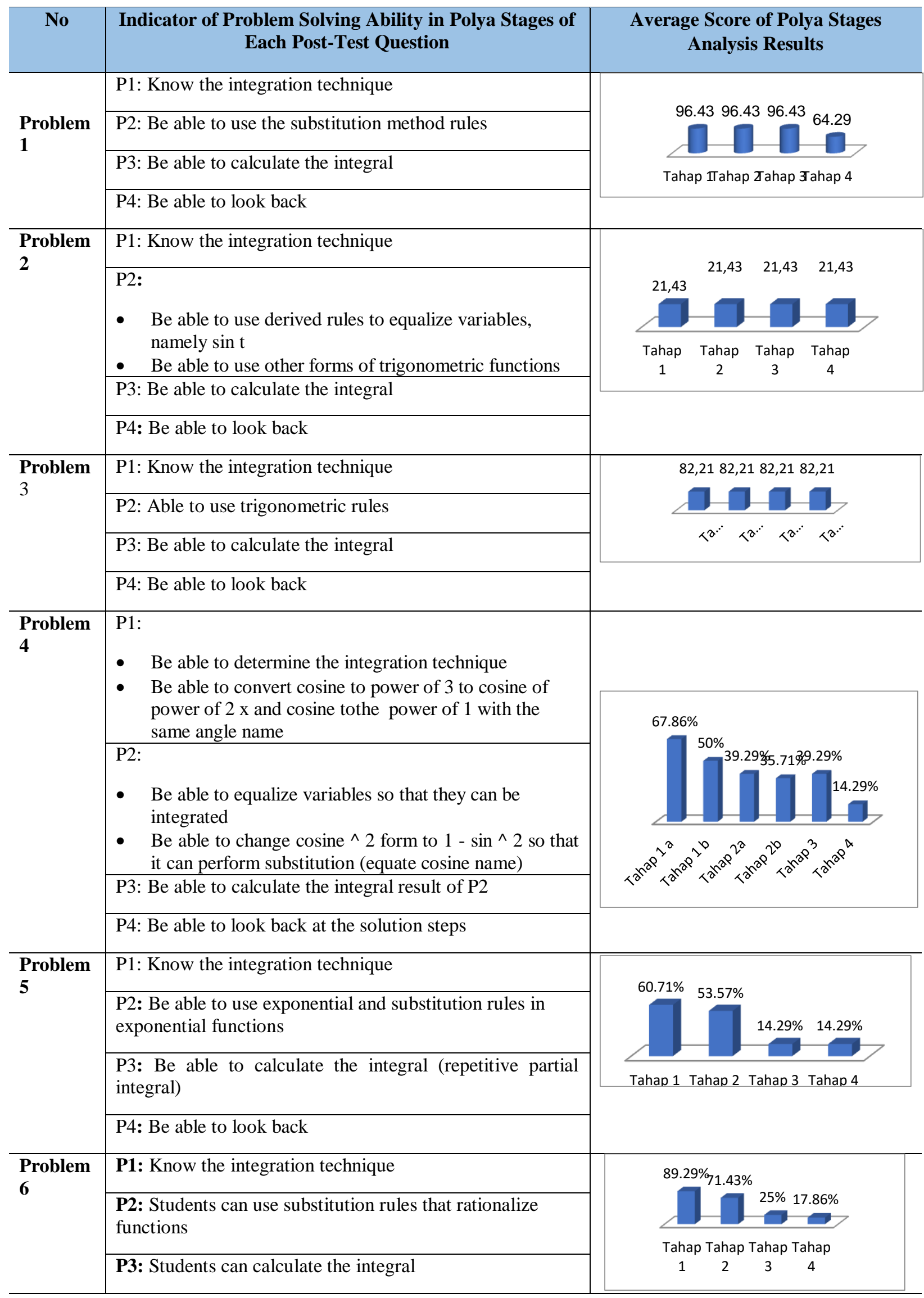




\begin{tabular}{|c|c|c|}
\hline No & $\begin{array}{c}\text { Indicator of Problem Solving Ability in Polya Stages of } \\
\text { Each Post-Test Question }\end{array}$ & $\begin{array}{c}\text { Average Score of Polya Stages } \\
\text { Analysis Results }\end{array}$ \\
\hline & P4: Be able to look back & \\
\hline \multirow{5}{*}{$\begin{array}{l}\text { Problem } \\
7\end{array}$} & P1: Students can make substitutions & \multirow{2}{*}{$82.14 \% 78.57 \% 67.86 \% 64.29 \%$} \\
\hline & $\begin{array}{l}\text { P2: Students can describe the questions based on the } \\
\text { denominator factor }\end{array}$ & \\
\hline & Students can do the substitutions & \multirow{3}{*}{$\begin{array}{cccc}\text { Tahap } & \text { Tahap } & \text { Tahap } & \text { Tahap } \\
1 & 2 & 3 & 4\end{array}$} \\
\hline & P3: Students can calculate the integral & \\
\hline & P4: Be able to look back & \\
\hline
\end{tabular}

Based on Table 2 above, it can be seen that in the indicator column, the contents of stage P1 were not exactly the same as in stage P1 in solving word problems using the Polya stage. For word questions, stage P1 contained the ability to read and understand story questions so that they were able to write down what was known and what was asked. P2 was able to write a formula to solve the story problem. At P3 they were able to use the formula in P2 to solve the word problems so that the final result was obtained. In P4, they were able to use other means besides the planned way. In Table 2, the method used to determine whether students had used the right way to solve and it can be seen from the first step in solving the problem. For the question number 1 , If a student started their first step by assuming $\mathrm{u}=\mathrm{x} 2$, then it was assumed that the student had understood the question and knew how to solve the problem and was able to solve it well. If it turned out that the final result was different, then it was likely that the students were not careful in their work. This was a signal that students were not rereading their answers. The same was done for other post-test question.

\subsection{Discussion}

Based on Table 2, it can be seen that question number 1 was about the integration technique substitution method and almost all students master it well. In previous research, it had also been proven that the application of the APOS Model in Integral Calculus learning can build character, critical, resilient, selfconfidence, and other characters [4][5][6]. Students who cannot solve question number one where at stage P1 were wrong from the first step, apparently, they cannot solve other Integration Technique questions, and this can be seen in Figure 1, some students got posttest scores $<30$. In general, students had difficulty solving the questions that concerned with trigonometric functions. Based on lecture notes, students who got posttest scores $>70$ were students who were active in learning both in small groups and in discussions in front of the class. The mistake that they made was not checking back the answers they have made, so they did not know that they are careless in carrying out the operation. Those made in the 'look back' stage are not enough [10], some students made look back just to complete the steps, not to rechecked their answer. Many students appear to believe that they finish their mission after solving a problem [11] [12]. In reality, they missed an important and instructive phase of the work [7]. In this situation, it is seen that, Polya's stages in integral volume problems the 'look back' stage is less care than the others [11].

If the learning outcomes were related to the student's ability to solve problems in a graphical form, the result is shown in Figure 3. 


\section{The Average Score of Post-Test and Polya's KPM}

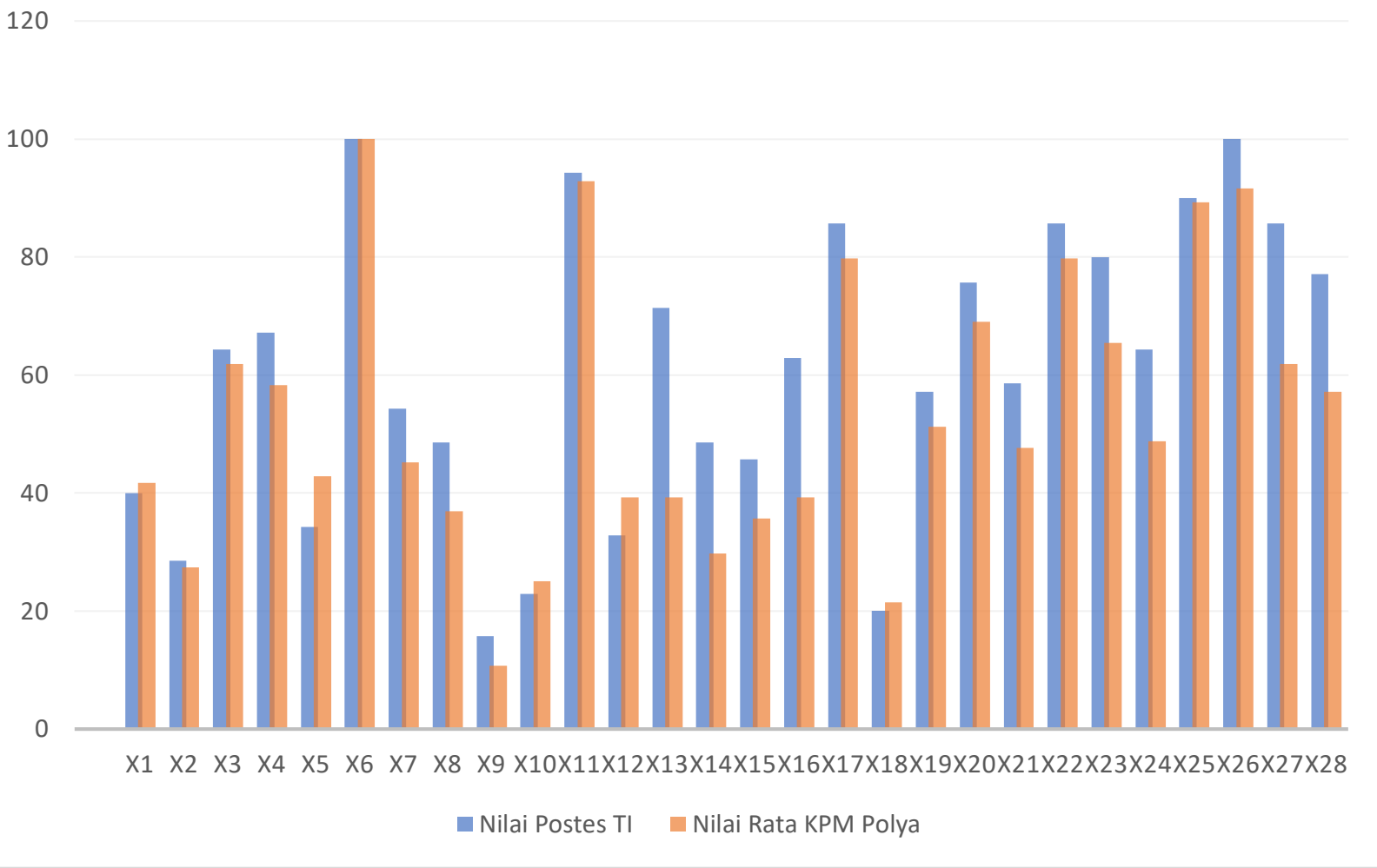

Figure 3. The Average Score of Posttest and Polya's KPM

Based on Figure 3, it can be seen that the value of learning outcomes for some students was higher than the value of the problem-solving ability of the post-test integration technique. The average score of the post-test results $=61.1$, and the average value of the post-test problem-solving ability of the integration technique = 53.19. One of the reasons why this happened was because of the value for problem-solving ability in terms of indicators was calculated using a value of zero for those who did nothing or a value of one for those who solved the problem according to the indicator. While learning outcomes used as an assessment rubric with a value interval between zero and 100 .

Problem-solving can help students to develop their understanding in terms of finding the strategy and ability to solve the problem and also understand the meaning of mathematics learning. At the four steps of Polya's, it can be concluded that the understand problem, let the students to explain and identify the information that obtained from the problem. In making a plan, let the student have an active role in find a strategy. In carrying out the plan, let them develop selfconfidence in capacities and skills for learning and thinking by themselves. At phase of look back, let them taking the time to reflect and look back at what they have done, what worked, and what did not [13]. Because of those activities, students can fastly or slowly develop their ability to solve the mathematics problem.

To find out whether the students had difficulty in answer each question, the last sheet of post-test questions was provided with a question that written: "Do you have difficulty answering each of the post-test questions? If yes, give the reason. Some students claimed that they did not experience difficulties because they had prepared themselves to face the posttest. Besides, students who answered "yes, difficulty", with the answer "confused about which integration technique should be used to solve each question". This result was not much different from the research results of Isnaini et al which states that: There were several reasons for students to made mistakes to solve the problems in integral calculus, including (1) student inaccuracy both in reading questions, writing mathematical symbols including integral symbols, and counting operations, (2) low mastery of prerequisite materials and basic mathematical concepts, (3) imperfect understanding of integral material and concepts, (4) students are less able to identify characters or types of questions to determine the appropriate integral technique, and (5) using formulas that are not adapted to the problem solving 
[14]. In order to solve the problem, students have to know the meaning of the problem, concept, formula, steps, and accuracy. Without those points, it will be difficult to solve mathematics problem and it is likely they will make a wrong solution to its problem.

\section{CONCLUSION}

Problem-solving in integral calculus for integration techniques can help students to develop their understanding in terms of finding the strategy and ability to solve the problem about integration techniques. Students who were active in learning both in small groups and discussions in front of the class did well on the problem-solving and got a score of more than 70. Based on the answers to the open questionnaire, the difficulty faced by students, in general, was the confusion in determining the formulas to be used especially for the integration technique of trigonometric functions.

\section{ACKNOWLEDGMENTS}

We thank the 3rd semester of undergraduate students at Mathematics Education Program of Bengkulu University in the academic year of 2019/2020 for their active participation as targeted samples in this study.

\section{REFERENCES}

[1] Purcell, Varberg, Rigdon, Jakarta: Kalkulus Jilid 1 Edisi Kedelapan. Erlangga, 2004.

[2] Hanifah, Model APOS Inovasi Pada Pembelajaran Matematika, FKIP Press. Bengkulu, 2016.

[3] Hanifah, Model APOS Pembelajaran Berbantuan Komputer, Bengkulu: CV. Zigie Utama, 2018.

[4] Hanifah and N. A. Irsal, N A, The Effectivity of APOS Model Based Worksheets on the Improper Integral, in: Journal of Physics: Conference Series 1317, 2019, pp. 1-12. DOI: 10.1088/1742$6596 / 1317 / 1 / 012115$

[5] Hanifah and N.A. Irsal, Learning Integration Techniques By APOS Model And Analysis Of Student's Error, in: International Journal of
Scientific and Technology Research, vol. 8, issue 12, 2019, pp. 146-153

[6] Hanifah, Building Critical, Tenacious, and Confident Characters through Application of APOS Model: Case study in integral calculus learning, in: 1st International Conference on Educational Sciences and Teacher Profession, 2018, pp. 107-111.

[7] G. Polya, How to Solve It (2nd ed.). Princeton, New Jersey: Princeton University Press, 1973

[8] G. Polya, "How to Solve It", 2nd ed., Princeton University Press, 1957, ISBN: 0-69108097-6.

[9] Purcell, Varberg, Rigdon, Kalkulus Jilid 1 dan Jilid 2 Edisi Sepuluh, Jakarta: Erlangga, 2010.

[10] E. Özkan Ergene and D. Ali, The weakest link of Polya's stages through integral problem solving process: what to check, in: Proceedings of the British Society for Research into Learning Mathematics, Vol. 36, No. 1, February 2016, pp. 30-36.

[11] S. Y, Lee, Students' Use of "Look Back" Strategies in Multiple Solution Methods, in: International Journal of Sciences and Math Education, Vol. 14, 2015. DOI: $10.1007 / \mathrm{s} 10763-014-9599-9$

[12] T. Jacobbe, K. Libby and T. A. Evitts, Using Polya to overcome translation difficulties, in: National Council of Teachers of Mathematics, Vol. 101, No. 5, 2007, pp. 390-393.

[13] P. LASAK, The Effects of Polya's Problem Solving Process on Mathematics Problem Solving Skills and Achievement of Mathematics Student Teachers, in: Proceedings of ISER 58th International Conference, Kobe, Japan, 6th -7 th June 2017, pp. 27-30.

[14] I. U. Machromah and M. E. Rosaria Purnomo, Process Skill Error: The Majority Student's Error in Problem Solving of Integral Calculus, in: Jurnal Daya Matematis, Vol. 5, No. 3, Desember 2017 , pp. 358-376. 